Sharif University of Technology
Scientia Iranica
SCIENTIA
IRAN I CA
http://scientiairanica.sharif.edu

\title{
Characteristics and time scale of local scour downstream stepped spillways
}

\author{
Y. Aminpour ${ }^{\mathrm{a}}$, J. Farhoudia,*, H. Khalili Shayan ${ }^{\mathrm{a}}$, and R. Roshan ${ }^{\mathrm{b}}$ \\ a. Department of Irrigation and Reclamation Engineering, University of Tehran, Karaj, P.O. Box 31587-4111, Iran. \\ b. Water Research Institute, Tehran, P.O. Box 16765-313, Iran. \\ Received 20 November 2015; received in revised form 27 August 2016; accepted 31 October 2016
}

\section{KEYWORDS}

Stepped spillway;

Local scour;

Time scale;

Stilling basin;

Hydraulic jump.

\begin{abstract}
Stepped spillways are employed to reduce excess energy encountered with exiting flow from high hydraulic structures. Study of local scour evolution downstream of stepped spillways wilt, therefore, provide the required information to reap the benefits made from these structures to minimize the scour hole dimensions. This paper provides the results of 67 experiments downstream of some stepped spillways subjected to different Froude numbers, basin lengths, tail-water depths, sediment sizes, and two different sloped spillways. The experiments were continued for $6,8,12$, and 24 hours from which 824 profiles and 85000 data points were recorded and analyzed. The results show that, in certain circumstances, the dimensions of scour hole increase in accordance with particle Froude number. It was also observed that an increase in the slope of spillway would result in reduction in the geometries of scour hole. Under certain conditions, as the tail-water increases, the depth of scour hole increases and elongates the hole. The relations of duration of scour evolution downstream of stepped spillway are presented in this paper. Finally, it was observed that the stepped spillway would considerably decrease the dimensions of scour hole compared with ogee spillways, reflecting the excess energy downstream loss of stepped spillway.

(C) 2018 Sharif University of Technology. All rights reserved.
\end{abstract}

\section{Introduction}

Local scour develops downstream of hydraulic structures due to insufficient energy loss and formation of eddy currents encountered with the flow coming out of such structures [1-5]. Stepped spillways, which have recently attracted design engineer's attention, are one of the most effective structures in reducing the excess energy of flow, which would result in the reduction of local scour dimensions compared with

*. Corresponding author. Tel.: +98 2632241119

E-mail addresses: Younes_aminpour@ut.ac.ir (Y.

Aminpour); jfarhoudi@ut.ac.ir (J. Farhoudi);

H_Kh_shayan@ut.ac.ir (H. Khalili Shayan);

rezaroshan2631@gmail.com (R.Roshan) ordinary spillways. Most of past studies on local scour were concentrated on downstream of chutes, Ogee spillways, and culverts. Few studies have focused on this downstream phenomenon of stepped spillways. Due to interesting features of stepped spillways in reduction of inflow energy and, consequently, in local scour dimensions, it would be important to study the evolution of local scour downstream of such structures.

Stepped spillways would dissipate the excess energy of water flowing over the spillway by means of steps. As a result, hydraulic jump downstream of these spillways would consist of less energy than that formed downstream of other spillways. Therefore, it is anticipated that the outgoing flow from these structures would be less capable of eroding the sediments from their immediate downstream.

In 1967, Breusers [6] experimentally studied the 
Table 1. Definition of experimental parameters.

\begin{tabular}{lcc}
\hline \multirow{2}{*}{ Parameters } & \multicolumn{2}{c}{ Range of parameters } \\
\cline { 2 - 3 } & Model I & Model II \\
\hline Flow discharge, $Q(\mathrm{lit} / \mathrm{s})$ & $7.4-29.9$ & $31.5-89$ \\
Sediment size, $D_{50}(\mathrm{~mm})$ & $0.58,1.11,1.78$ & $1.11,1.78$ \\
Height of steps of spillway, $h_{s}(\mathrm{~cm})$ & 3 & 4 \\
Width of steps of spillway, $l_{s}(\mathrm{~cm})$ & 5 & 10 \\
Length of stilling basin, $L_{B}(\mathrm{~cm})$ & $10,37,55,74,110$ & 120 \\
Height of stepped spillway, $H_{d}(\mathrm{~cm})$ & 45 & 60 \\
Width of the flume, $B(\mathrm{~cm})$ & 41 & 90 \\
Depth of tail-water, $y_{t w}(\mathrm{~cm})$ & $8-18.4$ & $11.6-21.7$ \\
Number of experiments & 55 & 12 \\
\hline
\end{tabular}

time evolution of local scour downstream of hydraulic structures and proposed a power equation to estimate the time scale for the phenomenon as follows:

$$
\frac{y_{\max }}{d_{0}}=\left(\frac{t}{t_{0}}\right)^{\alpha},
$$

where $y_{\max }$ is maximum depth of scour hole at time $t, d_{0}$ is the depth of scour hole at a certain time of $t_{0}$, and $\alpha$ is a parameter dependent on the type of structure and flow conditions. In 1985, Farhoudi and Smith [7] widely studied local scour evolution downstream of an ogee spillway and reported an equation similar to that of Breusers [6] for time scale of scour hole where $\alpha$ was estimated equal to 0.19. Ali and Lim [8] reported the effect of tail-water depth on dimensions of scour hole and suggested a limit for tail-water depth affecting the maximum scour depth. Lim [9] studied the effect of canal width on the evolution of local scour downstream of sluice gate, and found that if the ratio of canal width to the opening of gate is larger than 10, the variation of canal width would have no influence on the dimensions of scour hole. Balachandar et al. [10] considered the influence of particle sizes on the dynamics of local scour profiles downstream of sluice gate. Tuna and Emiroglu [11,12] investigated scour profiles downstream of stepped spillways for three types of different flow regimes. Results showed that the type of flow regime formed on stepped spillway has very important effect on maximum scour depth, such that, in a nappe flow regime, the maximum scour depth was less than that of skimming flow regime. Emiroglu and Tuna [13] investigated the effects of tail water depth on local scour downstream of stepped spillways. They concluded that scour hole dimensions will increase with an increase in tail water depth.

This paper highlights the result of an experimental study on local scour downstream of a stepped spillway in which the influences of various parameters, such as flow conditions, spillway geometries, time length, and energy downstream loss of the structure, were considered.

\section{Experimental layouts and procedures}

The experiments were conducted using two separate flumes where three different sizes of sand were subjected to different flow conditions downstream of stepped spillways with different layouts, whose dimensions are described in Table 1 . The characteristics of experimental layouts are presented in Figure 1(a). The schematic sketch of the experimental layout is shown in Figure 1(b), where a stepped spillway was operated with a stilling pool of varying lengths. The size distribution of the used sediments is shown in Figure 2. The incoming flow was measured by means of either a magnetic flow meter or a pre-calibrated sharp crested rectangular weir. The water level was recorded by means of a point gage with accuracy of $\pm 0.1 \mathrm{~mm}$. The dimensions of scour hole were recorded using a precise leveled digital camera. The recorded pictures, like Figure 3, were then retrieved to take advantage of Grapher7 from which the profiles of scour hole were recorded.

\section{Analysis of experimental data}

\subsection{Parameters influencing local scour downstream of stepped spillway}

To analyze the experimental data, it is of utmost importance to identify and define the effective parameters of the phenomenon, which can be summarized as follows:

$$
\begin{gathered}
F(\text { Scour })=f\left(y_{m}, x_{m}, x_{s}\right) \rightarrow f\left(y_{m}, x_{m}, x_{s}\right) \\
=f\left(\rho, \mu, D_{50}, \rho_{s}, \sigma_{g}, C_{u}, \phi, F S, h_{s}, l_{s},\right. \\
\left.L_{B}, H_{d}, q, y_{t w}, g, t\right),
\end{gathered}
$$

where $y_{m}$ and $x_{s}$ are maximum depth and length of 


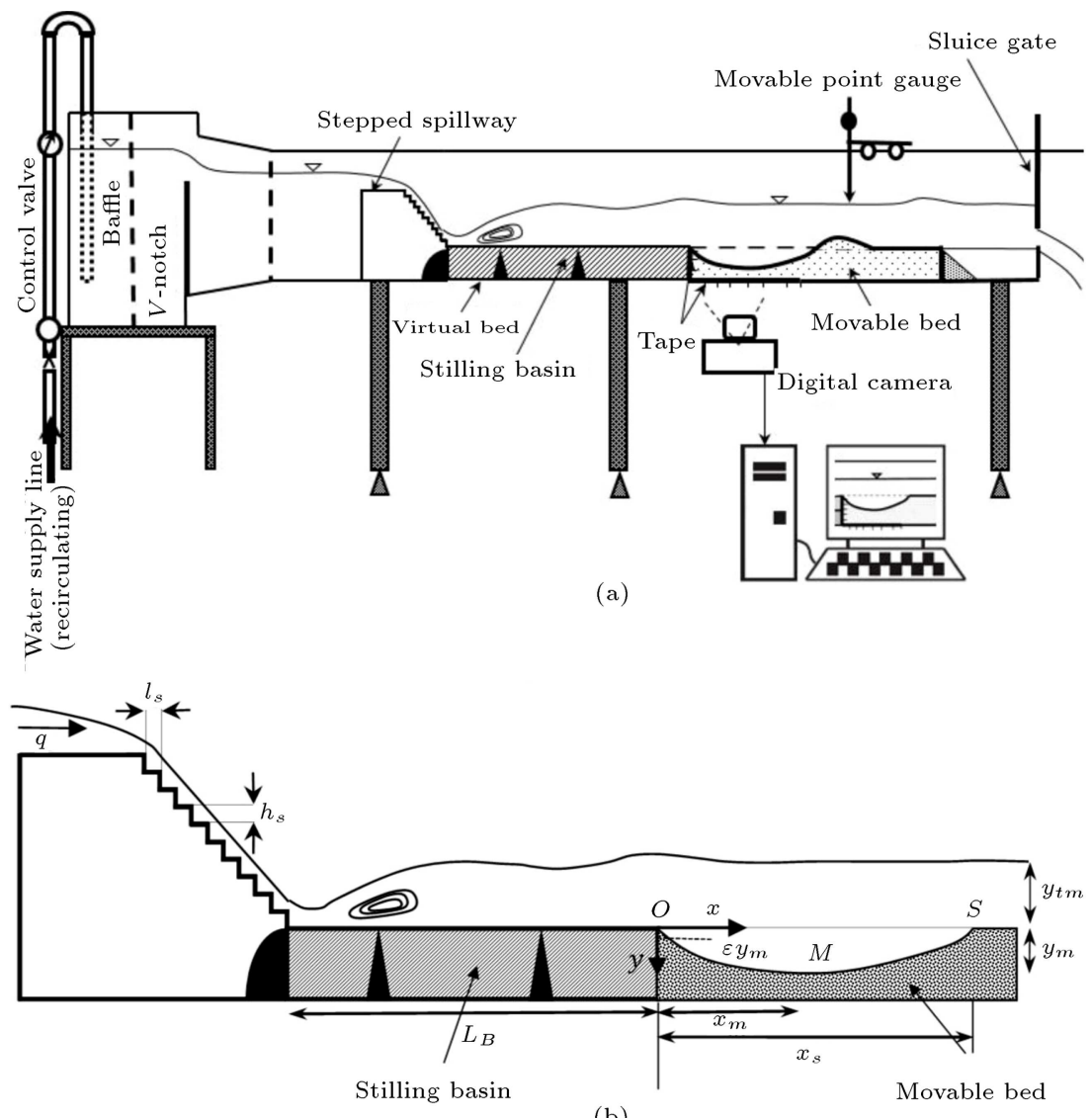

(b)

Figure 1. Experimental layout and effective parameters.

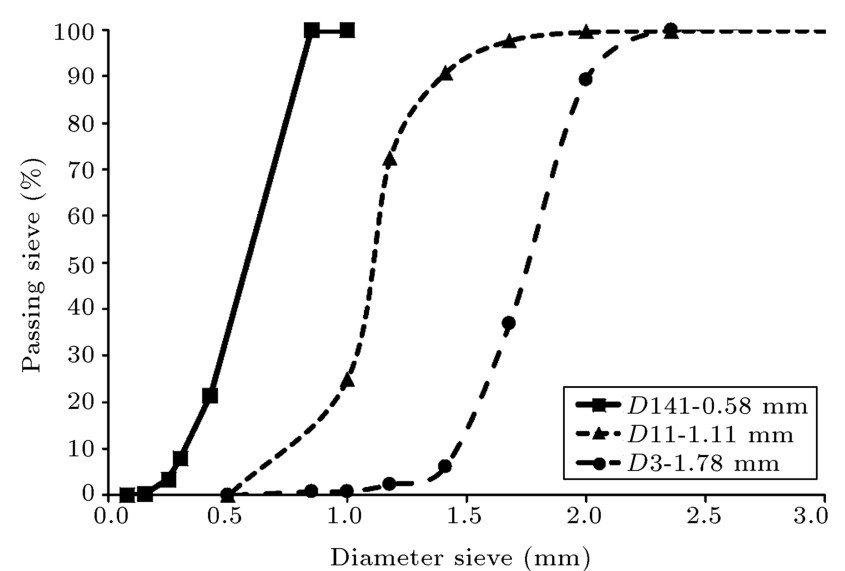

Figure 2. Size distribution of used sediments.

scour hole, respectively, $x_{m}$ is the longitudinal position of maximum depth from stilling basin, $\rho$ and $\mu$ are mass density and dynamic viscosity of water, respectively, $D_{50}$ is the size of sediment in which 50 percent of sediments are finer than $\rho_{s}$ which is mass density of sediments, $\sigma_{g}$ is geometric standard deviation of sediments, $C_{u}$ is uniformity coefficient of sediments, $\phi$ is angle of repose, $F S$ is shape factor of sediments, $h_{s}$ and $l_{s}$ are the height and length of steps, respectively, $L_{B}$ is the length of stilling basin, $H_{d}$ is the height of spillway, $q$ is the discharge intensity, $y_{t w}$ is tail-water depth, $g$ is acceleration due to gravity, and $t$ is the time.

Since the selected sediments were assumed to be granular and also had a uniform distribution, $C_{u}, \sigma_{g}$ and $F S$ could be relaxed. On the other hand, the angle of repose could be assumed constant as 35 degrees. Furthermore, the number of steps on the spillway was fixed to 15 ; therefore, the effect of $h_{s}$ could be compensated by using $H_{d}$. Consequently, Eq. (2) could be summarized as follows:

$$
F\left(\rho, \mu, \rho_{s}, D_{50}, h_{s}, l_{s}, L_{B}, q, y_{t w}, g, t, y_{m}, x_{m}, x_{s}\right)=0 \text {. }
$$

Taking benefits of Buckingham theorem, Eq. (3) could be written in a non-dimensional form as follows:

$$
f\left(\frac{h_{s}}{l_{s}}, \frac{L_{B}}{D_{50}}, \frac{y_{t w}}{D_{50}}, \frac{t}{t_{0}}, \mathrm{R}_{\mathrm{e}}, \mathrm{Fr}_{D}, \frac{y_{m}}{D_{50}}, \frac{x_{m}}{D_{50}}, \frac{x_{s}}{D_{50}}\right)=0 .
$$

Since during the experiments $\operatorname{Re}>4000$, the effect of Reynolds number could be overlooked. It should be clarified that $t_{0}=\frac{h_{s}^{2}}{\sqrt{g\left(S_{s}-1\right) D_{50}^{3}}}$ and $\operatorname{Fr}_{D}=\frac{q}{\sqrt{g\left(S_{s}-1\right) D_{50}^{3}}}$ (particle Froude number) were defined where $S_{s}=\frac{\rho_{s}}{\rho}$. Taking a note of these clarifications, Eq. (4), thereafter, will be the base of data analysis. 


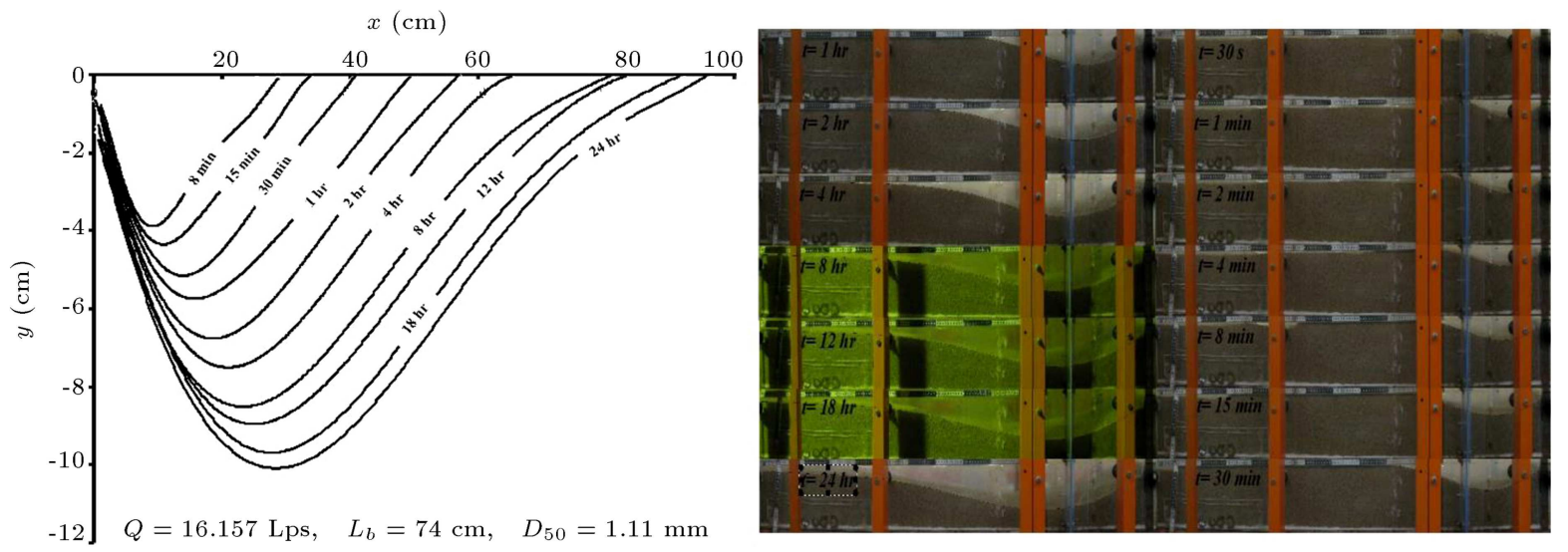

Figure 3. Sample pictures and retrieved scour hole profiles.
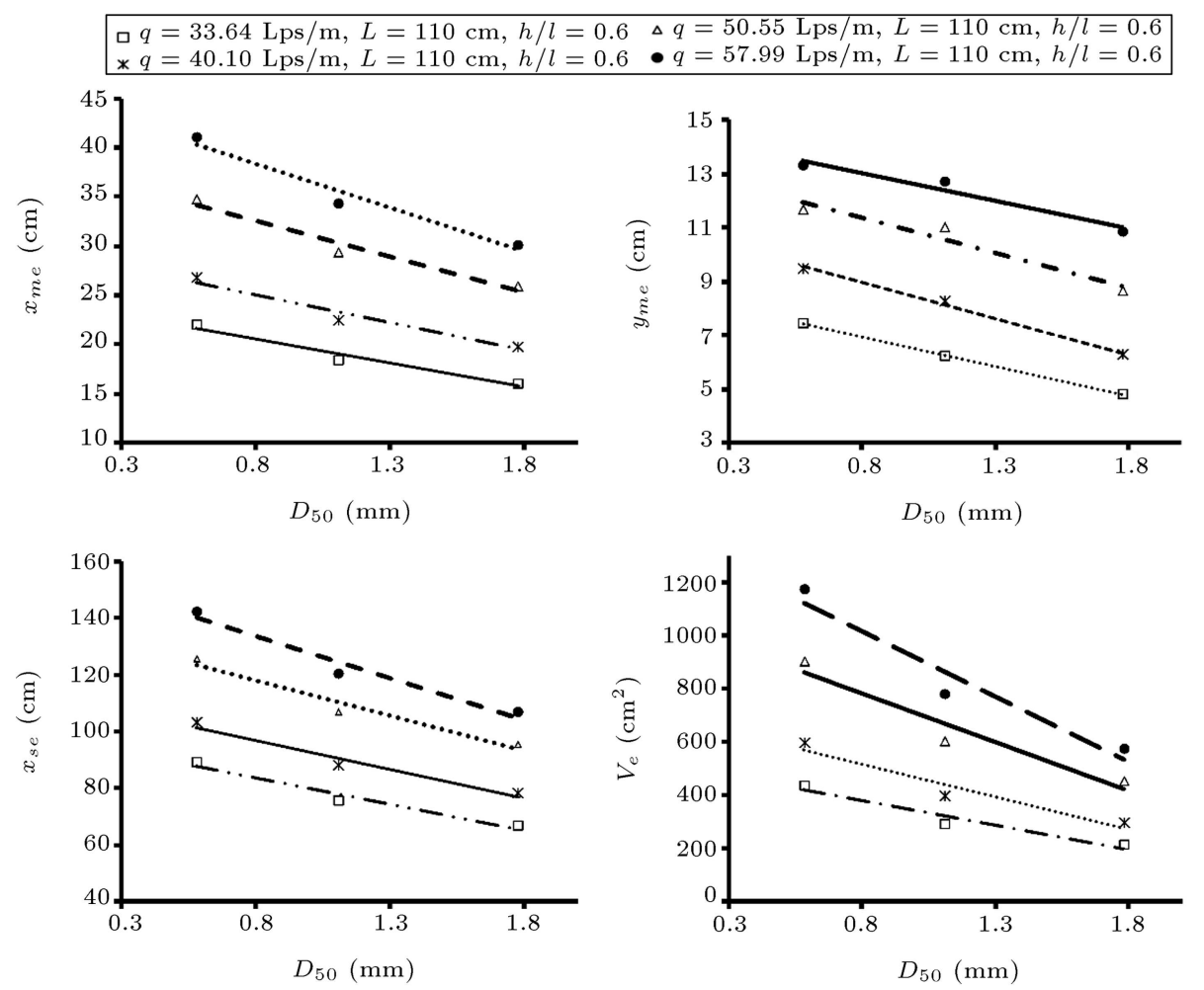

Figure 4. The effect of sediment size on the dimensions of scour hole.

\subsection{The influence of various parameters on dimensions of scour hole}

\subsubsection{Effects of sediment size}

Figure 4 shows the effect of sediment sizes on the geometries of scour hole. It is clear from the figure that the dimensions of scour hole show an adverse trend with sediment sizes. This is because of direct proportionality of shear stress with sediment size. Therefore, it is expected that the scour hole achieve smaller dimensions with larger sediments.

\subsubsection{Effects of the length of stilling basin}

Figure 5 depicts the effects of the length of stilling basin on the geometries of scour hole. It was ob- served that an increase in the length of the stilling basin would inversely affect the dimensions of scour hole. This could be related to the higher energy losses inside the longer stilling basins. It means that as the stilling basin becomes longer, the amount of energy transported to downstream of structure decreases, which leaves less potential to erode the bed materials.

\subsubsection{The influence of sediment Froude number on dimensions of scour hole}

Figure 6 shows the impacts of Froude number on the geometries of scour hole downstream of stepped spillways. It was observed that $\operatorname{Fr}_{D}$ directly af- 

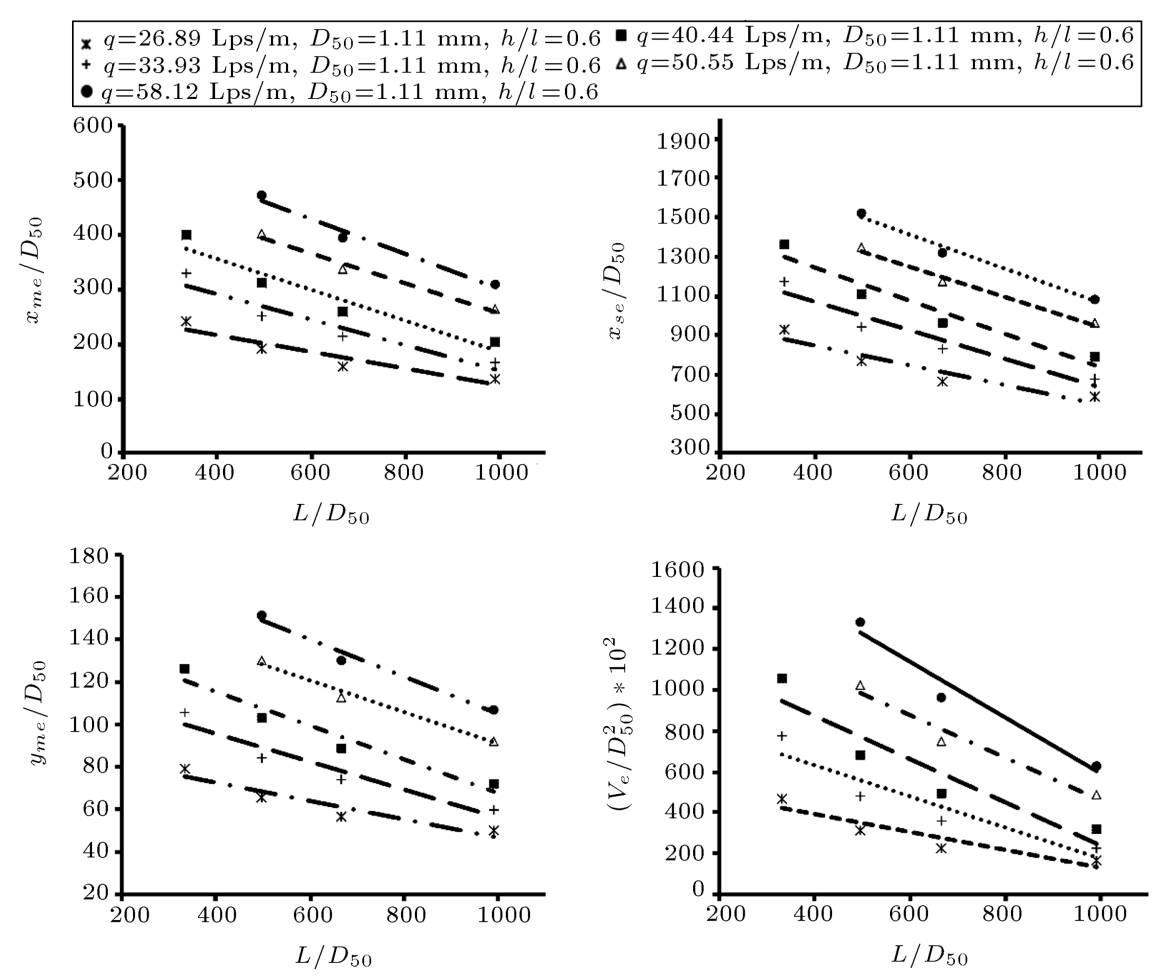

Figure 5. Impacts created by the length of stilling basins on the dimensions of scour hole.
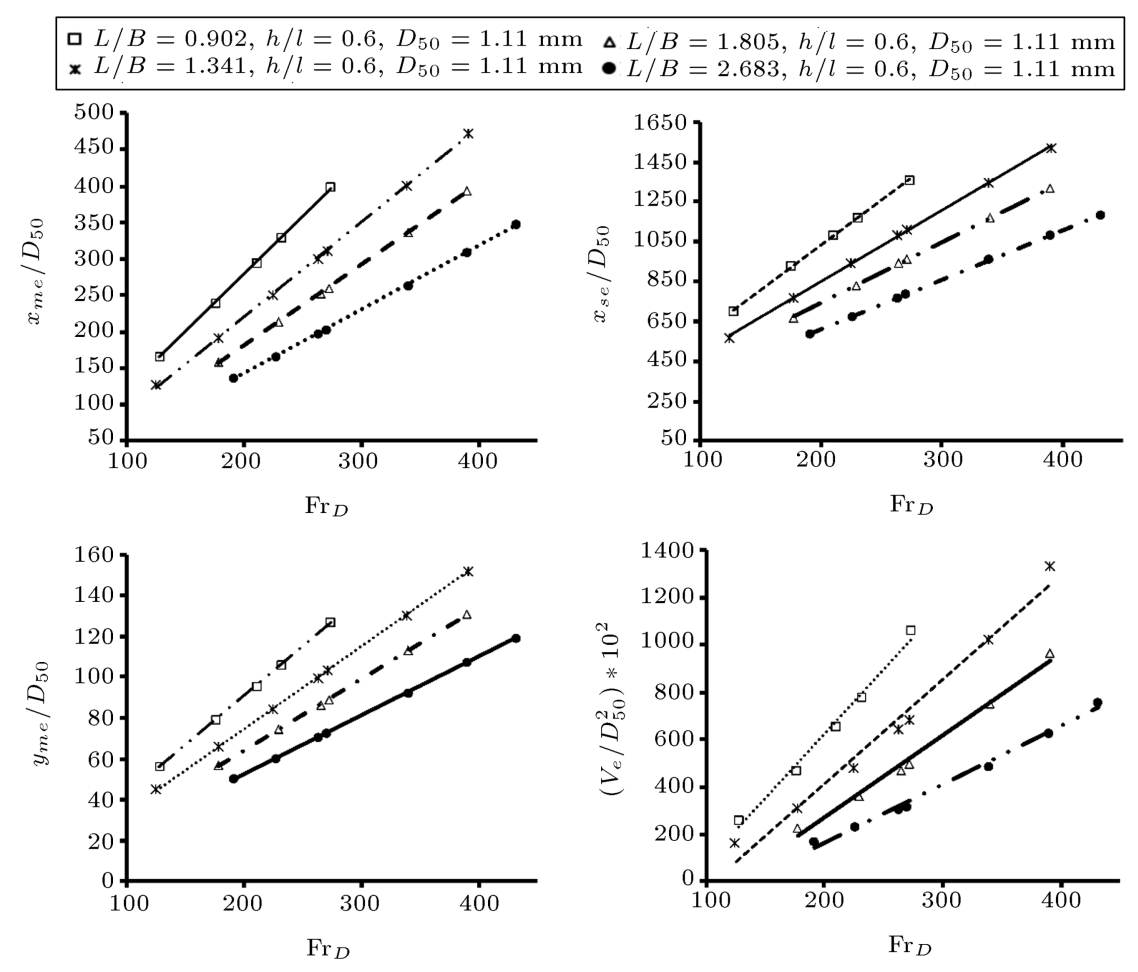

Figure 6. Influence of Froude number on dimensions of scour hole.

fects the dimensions of scour hole. This is because of inherent influence of flow discharge embedded in $\operatorname{Fr}_{D}$, which affects the energy loss in stilling basin as well as the shear stress acting on the bed.

\subsubsection{The influence of spillway slope on dimensions of scour hole}

The influences of spillway slope on dimensions of scour hole are depicted in Figure 7, showing that as the slope increases (higher spillway), the geometries of scour 

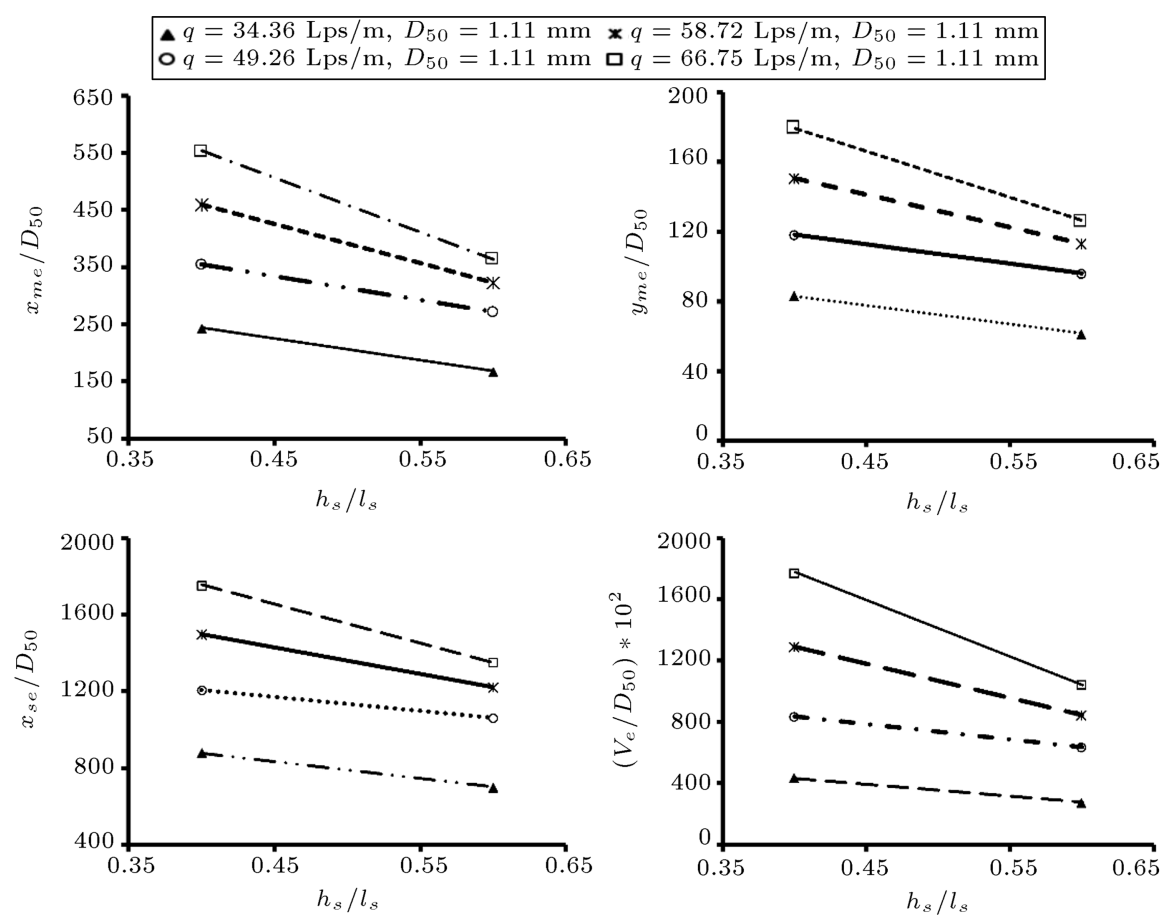

Figure 7. Influence of steps slope on dimensions of scour hole.
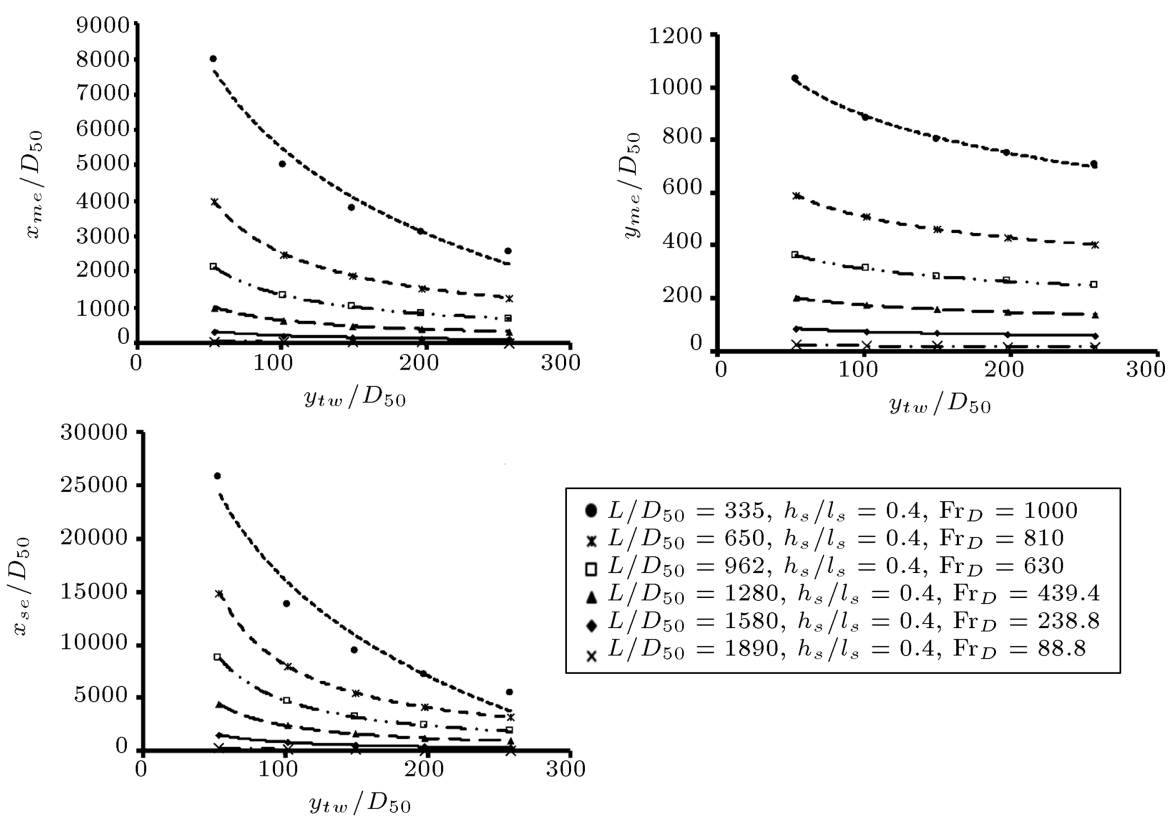

Figure 8. Influence of tail-water depth on the dimensions of scour hole.

hole at its maximum stage decrease. This could be attributed to larger energy losses with higher spillways as reported by Chanson [14]. Figure 7 shows the effect of steps slope on scour geometry and, consequently, the effect of spillway slope.

\subsubsection{Influence of tail-water depth on the dimensions of scour hole}

The experimental observations recorded from the effects of tail-water depth variation scour hole character- istics are demonstrated in Figure 8, showing an indirect role in the development of scour hole dimensions. This would be related to the decrease in flow velocity with deeper tail-water, resulting in lower energy available for eroding the flow bed.

\subsection{Time Scale of scour hole downstream of stepped spillway}

As previously mentioned, Breusers [6] expressed the time scale of scour evolution by an exponential equa- 

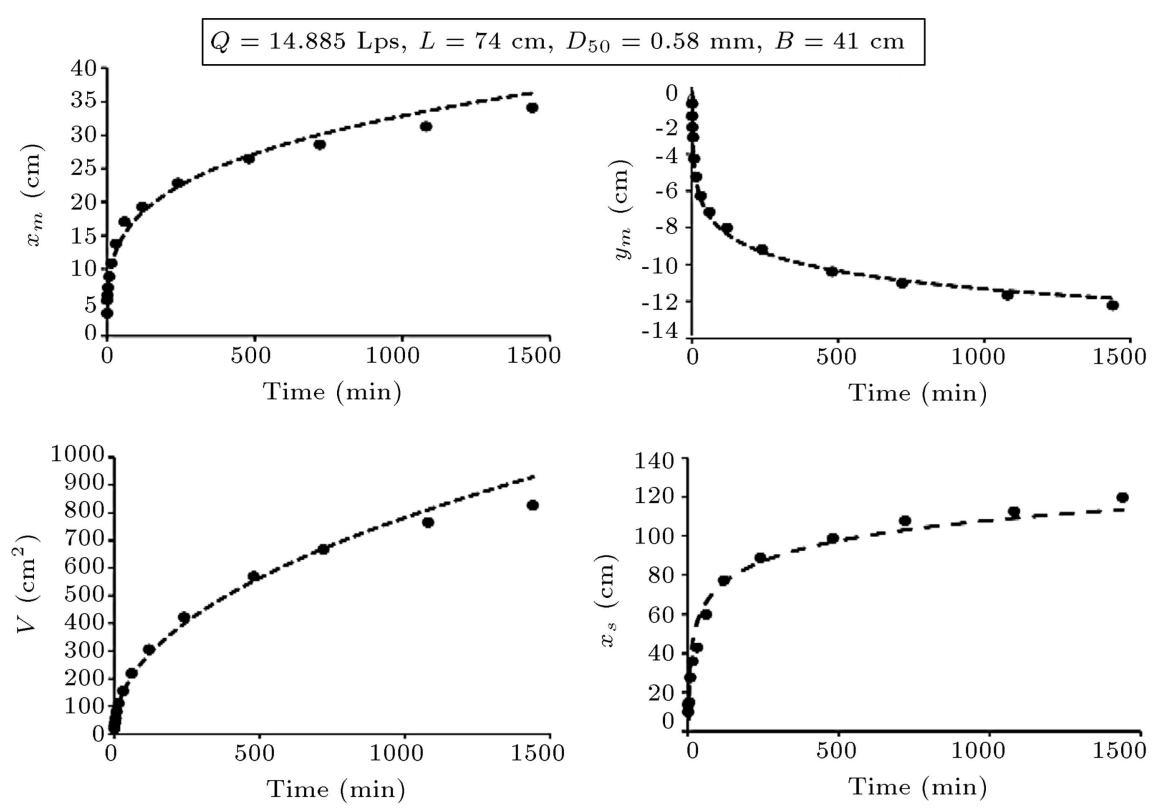

Figure 9. Changes of scour hole and the volume of sediment transported by time.

tion, later addressed by many researchers. His proposed equation was employed for scour development downstream of stepped spillways with stilling basin and revised according to experimental results. Figure 9 depicts the ultimate maximum scour depth $\left(y_{m}\right)$, distance from maximum scour depth to the end of stilling basin $\left(x_{m}\right)$, length of scour hole $\left(x_{s}\right)$, and transported sediment volume from the hole $(V)$ with time. According to the figures, the upstream section of scour hole will reach its equilibrium stage sooner than the downstream section of hole. Due to the experimental restrictions, the time interval for equilibrium was selected as 24 hours. However, some longer periods would be required for the satisfaction of relative equilibrium state. In equilibrium stage, the position of maximum depth of scour hole almost stands stable. However, due to inverse eddies action, the sediment moves towards the upstream face of the hole, changing the configuration of scour hole. Accordingly, the dynamic equilibrium of bed cannot be reached even in longer time intervals.
Balachandar et al. [10] referred to this fact according to their experiments at 96 hours. Therefore, it would be wise to use the term "semi-equilibrium stage" instead of "equilibrium stage".

In order to investigate the possibility of similarity between maximum scour geometry and time, Breusers [6] proposed the following equation:

$$
\frac{y_{\max }}{d_{0}}=k\left(\frac{t}{T}\right)^{\alpha}
$$

where $y_{\max }$ is the maximum depth of scour hole after time $t, T$ is the time when water depth reaches $d_{0}$, which is a length parameter related to the structure dimension referred to as characteristic depth, $k$ and $\alpha$ were calculated according to experimental results. Figure 10(a) shows the variation of $\frac{y_{\max }}{d_{0}}$ with time ratio $\frac{t}{T}$ which would facilitate to determine $k$ and $\alpha$ values for experimental data. In this research, characteristic depth, $d_{0}$, is considered twice the steps height $\left(d_{0}=\right.$

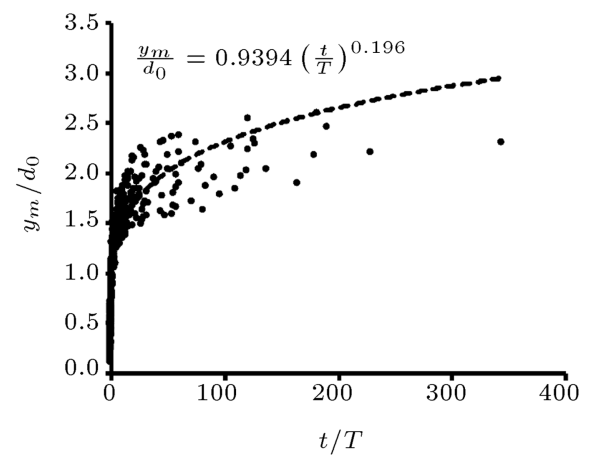

(a)

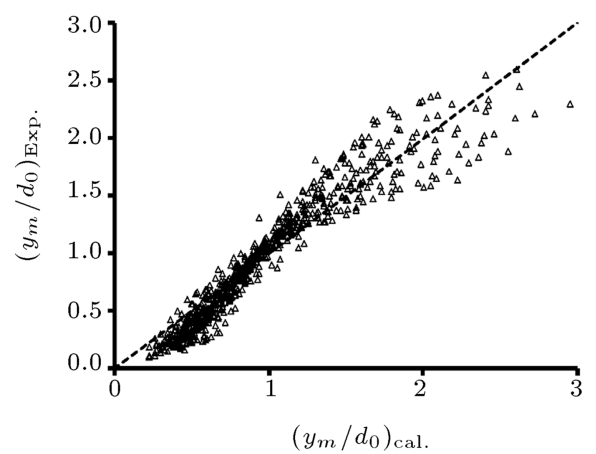

(b)

Figure 10. (a) Determining factor $k$ and $\alpha$ based on laboratory data. (b) Evaluating the accuracy of Eq. (5). 
Table 2. A comparison between $k$ and $\alpha$ values for different hydraulic structures reported by previous researchers.

\begin{tabular}{lllc}
\hline \multicolumn{1}{c}{ Structural type } & Researcher & $\boldsymbol{k}$ & $\boldsymbol{\alpha}$ \\
\hline River entries without hydraulic jump formation & Breuser (1967) $[6]$ & 1.00 & 0.38 \\
Ogee spillway without end sill & Farhoudi and Smith (1982) [16] & 1.00 & 0.19 \\
Ogee spillway with the end sill & Oliveto and et al (2011) [17] & 0.92 & 0.20 \\
Ogee spillway & Dargahi (2003) [18] & 1.00 & $\alpha=-0.17 \ln \left(\frac{h_{0}}{h_{d}}\right)+0.04$ \\
Sluice gate with horizontal stilling basin & Farhoudi and Shayan (2014) $[19]$ & 0.99 & 0.32 \\
Stepped spillway & Present work & 0.94 & 0.196 \\
\hline
\end{tabular}

Table 3. Range of effective parameters in Farhoudi and Smith (1980) [15].

\begin{tabular}{lcccc}
\hline $\begin{array}{c}\text { Spillway } \\
\text { height } \\
(\mathbf{c m})\end{array}$ & $\begin{array}{c}\text { Discharge } \\
\text { range } \\
(\mathbf{l i t} / \mathbf{s})\end{array}$ & $\begin{array}{c}\text { Length of } \\
\text { stilling basin } \\
(\mathbf{c m})\end{array}$ & $\begin{array}{c}\text { Sediment particle } \\
\text { size distribution } \\
(\mathbf{m m})\end{array}$ & $\begin{array}{c}\text { Profile of } \\
\text { ogee spillway }\end{array}$ \\
\hline Small (10) & $8.3-25$ & 41.5 & Sand $(0.15,0.25,0.52,0.85)$ & $y=-0.1806 x^{1.872}$ \\
Medium (20) & $23.3-70$ & 83 & Bakelite $(0.25,0.52)$ & \\
Large (40) & $66-198$ & 166 & & \\
\hline
\end{tabular}

$\left.2 h_{s}\right)$. In each experiment, $T$ values were interpolated between maximum depths of scour with time when a magnitude of $2 h_{s}$ is reached. The values of $k$ and $\alpha$ were determined as 0.9394 and 0.196 , respectively, from Figure 10. The following equation was used to calculate $T$ values:

$$
\begin{gathered}
\frac{T}{t_{0}}=2258.62\left(\frac{l_{s}}{D_{50}}\right)^{-2.0955}\left(\frac{h_{s}}{D_{50}}\right)^{2.796} \\
\left(\frac{L_{B}}{D_{50}}\right)^{3.931}\left(\operatorname{Fr}_{D}\right)^{-5.0532}
\end{gathered}
$$

Figure 10(b) was also used to evaluate the accuracy of Eq. (5). Table 2 shows $k$ and $\alpha$ values downstream of various hydraulic structures obtained by various researchers. It is observed that after a while, scour depth downstream of stepped spillways is less than that of ogee spillways and gate valves. In other words, because of further energy dissipation through stepped spillways, the time needed for achieving special scour depth is much longer than ordinary spillways. A reduction in $k$ and $\alpha$ values is expected as the flow characteristics tend towards the nappe flow condition.

\subsection{Role of stepped spillways in reducing the scour hole geometries compared with ogee spillways}

One of the advantages of stepped spillways compared with ogee spillways is its high-energy dissipation, which would end with smaller dimensions of scour hole downstream of these structures. To clarify this prediction, Farhoudi's data [15] for scour evolution downstream of ogee spillways were used. The study was conducted on three ogee spillways with different heights. Table 3 shows the structure details and ranges of different parameters in brief.

These researchers studied the process of scour development and counter effects of hydraulic jump under high, low, and balanced tail-water depths. In order to compare the effects of stepped spillways with ogee spillways on the development of scour hole, 20 series of Farhoudi's data [15] from experiments under balanced tail water were selected. For each series of experiments, maximum scour hole depth $\left(y_{m}\right)$, distance of maximum scour hole depth from end of stilling basin $\left(x_{m}\right)$, and scour hole length $\left(x_{s}\right)$ were determined for equilibrium conditions. The relationship between particle Froude number and relative scour hole dimensions was then calculated, depicted in Figure 11 for both structures. Figure 11 shows that, in a certain flow condition and specific range of particle Froude number, the relative depth of scour $\left(\frac{y_{m}}{D_{50}}\right)$ in stepped spillway is less than that of ogee spillway. This observation explains that with the higher energy dissipation caused by stepped spillway, the scour hole dimensions will be considerably less than those observed with ogee spillways.

Chanson [14] proposed the following relationship for calculating energy dissipation by stepped spillway in nappe flow condition:

$$
\frac{\Delta H}{H_{\max }}=1-\left(\frac{\left(\frac{f_{e}}{8 \sin \theta}\right)^{\left(\frac{1}{3}\right)} \cos \theta+\frac{1}{2}\left(\frac{f_{e}}{8 \sin \theta}\right)^{\left(\frac{-2}{3}\right)}}{\frac{3}{2}+\frac{H_{\mathrm{dam}}}{y_{c}}}\right)
$$

where $\Delta H$ is the value of energy dissipation by stepped 


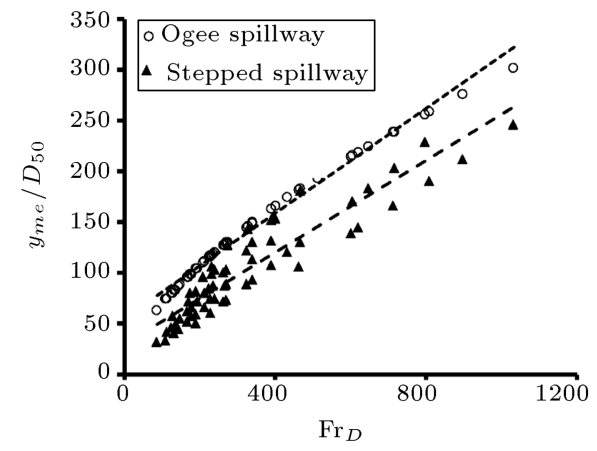

(a)

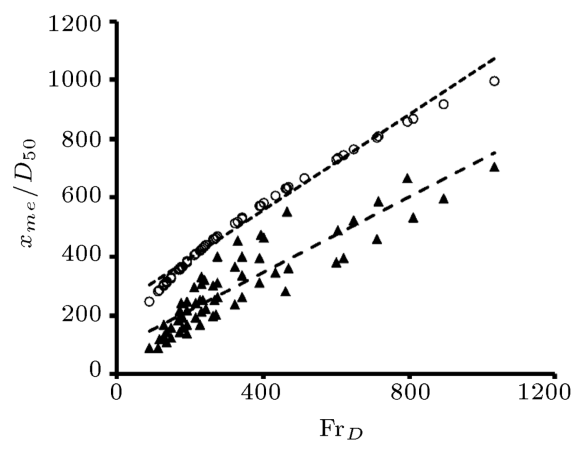

(b)

Figure 11. The relationship between particle Froude number and relative scour hole dimensions for ogee spillway .

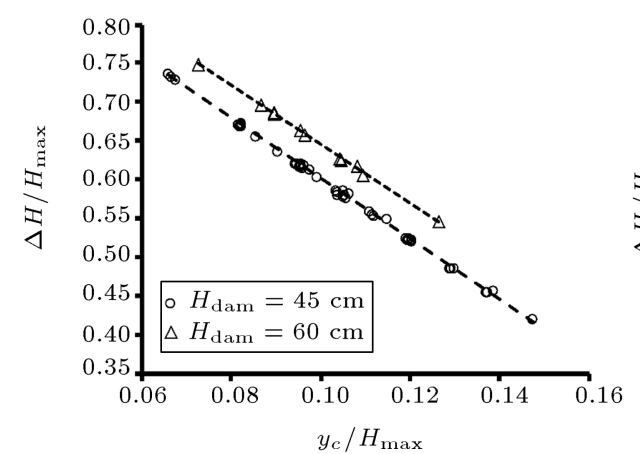

(a)

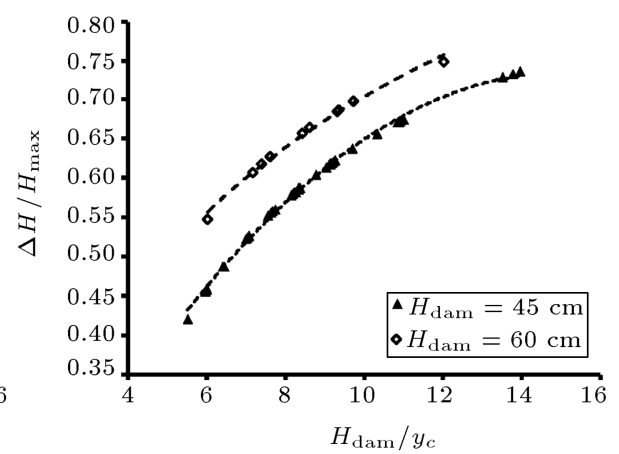

(b)

Figure 12. (a) The relationship between the rates of relative energy dissipation with critical depth. (b) The relationship between the rates of relative energy dissipation with Spillway height.

spillway. In addition, $H_{\text {dam }}$ is the spillway height, $H_{\max }$ is the total energy height upstream of spillway, which can be calculated from $H_{\max }=H_{\text {dam }}+y_{0}$, ( $y_{0}$ is water head on spillway crest), $f_{e}$ is the friction factor for water-air flows which is 0.2 for stepped spillway and 0.03 for ogee spillway, respectively, $\theta$ is the angle of spillway slope, and $y_{c}$ is the critical depth of flow. The relative energy loss for experimental data was calculated using Chanson equation and plotted in Figure 12. It could be observed from Figure 12(a) that, in a spillway of a specific height, an increase in flow discharge would significantly reduce the energy loss. On the other hand, Figure 12(b) shows that, under specific discharge, as the height of spillway increases, the energy dissipation decreases, confirming the achievement of Chanson [14]. It could be concluded that the existence of steps in stepped spillways will cause higher energy loss of 42.06 to 74.82 compared with ogee spillways.

In Figure 13, the relationship between relative energy loss of stepped spillway, scour hole geometry and volume of transported sediments of size $D_{50}=$ $1.11 \mathrm{~mm}$ to downstream of a stilling basin of $110 \mathrm{~cm}$ length is shown. According to this figure, as the energy loss by stepped spillway decreases, the dimensions of scour hole as well as the volume of transported sediments out of the hole significantly increase.

\section{Conclusion}

From wide ranges of experiments downstream of some stepped spillways subjected to different Froude numbers, basin lengths, tail-water depths, sediment sizes, and different sloped spillways, the following remarks could be concluded. With certain length of stilling basin, relative tail water and particle Froude number, the scour hole geometry will decrease with sediment size. On the other hand, with fixed sediment sizes, slope of stepped spillway, relative tail water and particles Froude number, the geometry of scour hole will decrease as the length of stilling basin increases. An increase in particles Froude number with constant values of other parameters would tend to an increase in the dimensions of scour hole. As the slope of stepped spillway increases, the geometries of scour hole decrease. Under constant conditions, an increase in tail-water depth would end with deeper scour hole having a longer longitudinal length. An exponential equation would predict the time scale of scour evolution downstream of stepped spillway.

It was concluded that the energy dissipation of stepped spillways under specific condition is higher than that of ogee spillways. This would result in smaller dimensions of scour hole and longer time required to reach the semi-equilibrium stage, i.e. down- 

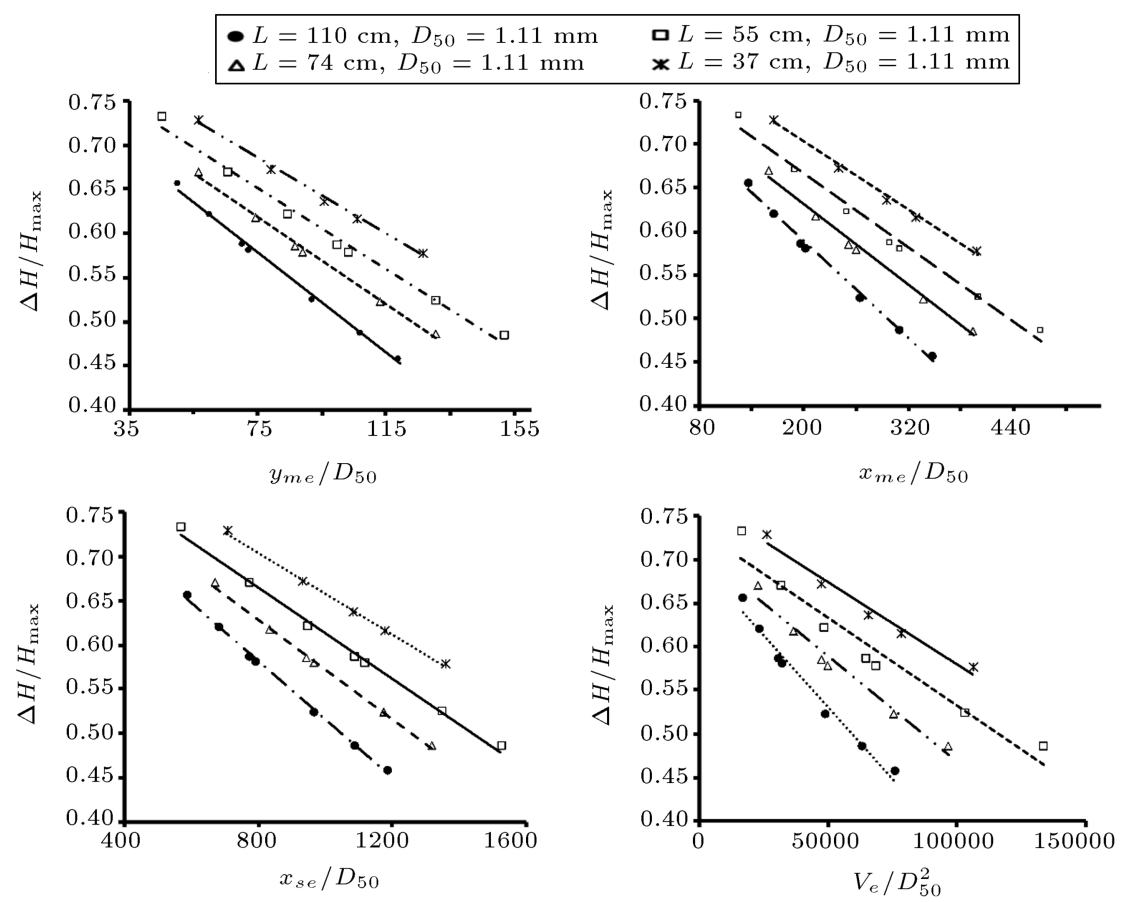

Figure 13. The relationship between the relative energy dissipation by stepped spillway and dimensions of scour hole.

stream of these structures compared with that of ogee spillways being the same.

\section{Nomenclature}

$B \quad$ Width of the flume $(\mathrm{cm})$

$C_{u} \quad$ Uniformity coefficient of sediments

$D_{50} \quad$ Sediment size $(\mathrm{cm})$

$\operatorname{Fr}_{D} \quad$ Particle Froude number

FS Shape factor of sediments

$H_{d} \quad$ Height of stepped spillway $(\mathrm{cm})$

$H_{\max } \quad$ Total energy height upstream of spillway

$L \quad$ Length of stilling basin $(\mathrm{cm})$

$Q \quad$ Flow discharge (lit/s)

$T \quad$ Time required the scour depth reaches $d_{0}$

$V \quad$ Volume of transmitted Sediments from hole

$f_{e} \quad$ Friction factor

$y_{m} \quad$ Maximum depth of scour hole $(\mathrm{cm})$

$x_{m} \quad$ Position of maximum depth from stilling basin $(\mathrm{cm})$

$x_{s} \quad$ Maximum length of scour hole $(\mathrm{cm})$

$q \quad$ Discharge intensity $\left(\frac{\mathrm{lit} / \mathrm{s}}{\mathrm{m}}\right)$

$y_{\max } \quad$ Maximum depth of scour hole at time $t$

$d_{0} \quad$ Depth of scour hole at a certain time $t_{0}$
Water head on spillway crest

Height of steps of spillway $(\mathrm{cm})$

Acceleration due to gravity $\left(\mathrm{m} / \mathrm{s}^{2}\right)$

Time

$t$

$y_{t w} \quad$ Depth of tail-water $(\mathrm{cm})$

$\alpha \quad$ A parameter depending on the type of structure and flow conditions

$l \quad$ Width of steps of spillway $(\mathrm{cm})$

$y_{c} \quad$ Critical depth of flow

$\sigma_{g} \quad$ Geometric standard deviation of sediments

$\theta \quad$ Angle of Spillway slope

$\Delta H \quad$ Height of energy dissipation by stepped spillway

$\rho \quad$ Mass density of water $\left(\mathrm{kg} / \mathrm{m}^{3}\right)$

$\rho_{s} \quad$ Mass density of sediments $\left(\mathrm{kg} / \mathrm{m}^{3}\right)$

$\phi \quad$ Angle of repose

$\mu \quad$ Dynamic viscosity of water $\left(\frac{\mathrm{N}-\mathrm{s}}{\mathrm{m}^{2}}\right)$

\section{References}

1. Ahmad, N., Mohamed, T., Ali, F., and Yusuf, B. "Clear-water local scour at wide piers in shallow-water flow", Water Practice \& Technology, 9, pp. 331-343 (2014).

2. Ghodsian, M., Mehraein, M., and Ranjbar, H. "Local scour due to free fall jets in non-uniform sediment", Scientia Iranica, 19, pp. 1437-1444 (2012). 
3. Najafzadeh, M. and Barani, G.-A. "Comparison of group method of data handling based genetic programming and back propagation systems to predict scour depth around bridge piers", Scientia Iranica, 18, pp. 1207-1213 (2011).

4. Najafzadeh, M., Barani, G.-A., and Hessami-Kermani, M.-R. "Group method of data handling to predict scour depth around vertical piles under regular waves", Scientia Iranica, 20, pp. 406-413 (2013).

5. Shayan, H.K., and Farhoudi, J. "Local scour profiles downstream of adverse stilling basins", Scientia Iranica, Transactions A, Civil Engineering, 22, pp. 1-14 (2015).

6. Breusers, H.N.C. "Time scale of two-dimensional local scour", Proc. 12th IAHR Congress, Fort Collins, pp. 275-282 (1967).

7. Farhoudi, J. and Smith, K.V.H. "Local scour profiles downstream of hydraulic jump", Journal of Hydraulic Research, 23(4), pp. 343-358 (1985).

8. Ali, K. and Lim, S. "Local scour caused by submerged wall jets", Proceedings of the Institution of Civil Engineers, 81, pp. 607-645 (1986).

9. Lim, S.-Y. "Scour below unsubmerged full-flowing culvert outlets", Proceedings of the Institution of Civil Engineers, Water Maritime and Energy, 112, pp. 136149 (1995).

10. Balachandar, R., Kells, J.A., and Thiessen, R.J. "The effect of tail water depth on the dynamics of local scour", Canadian J. Civil Engineering, 27(1), pp. 138150 (2000).

11. Tuna, M. and Emiroglu, M. "Scour profiles at downstream of cascades", Scientia Iranica, 18, pp. 338-347 (2011).

12. Emiroglu, M.E. and Tuna, M.C. "The effect of tailwater depth on the local scour downstream of steppedchutes", KSCE Journal of Civil Engineering, 15, pp. 907-915 (2011).

13. Tuna, M. "Effect of offtake channel base angle of stepped spillway on scour hole", Iranian Journal of Science and Technology. Transactions of Civil Engineering, 36, pp. 239-251 (2012).

14. Chanson, H., Hydraulics of Stepped Chutes and Spillways, A.A. Balkema Publishers, Lisse, 384 pages, ISBN 90-5809-352-2 (2002).

15. Farhoudi, J. "Scaling Relationship for Local Scour Downstream of Stilling Basin", University of Southampton, Degree of Doctor of Philosophy (1980).

16. Farhoudi, J. and Smith, K.V. "Time scale for scour downstream of hydraulic jump", Journal of the Hydraulics Division, 108, pp. 1147-1162 (1982).

17. Oliveto, G., Comuniello, V., and Bulbule, T. "Timedependent local scour downstream of positive-step stilling basins", Journal of Hydraulic Research, 49, pp. 105-112 (2011).

18. Dargahi, B. "Scour development downstream of a spillway", Journal of hydraulic research, 41, pp. 417426 (2003).
19. Farhoudi, J. and Shayan, H.K. "Investigation on local scour downstream of adverse stilling basins", Ain Shams Engineering Journal, 5, pp. 361-375 (2014).

\section{Biographies}

Younes Aminpour received his BS degree in Water Engineering from Urmia University in 2012. He was accepted to study for an MEng Degree in Hydraulic Structures at University of Tehran. He is currently a PhD student at the Faculty of Agriculture Engineering and Technology at the University of Tehran. His research interests include: sediment scour in hydraulic structures, energy dissipation, stilling basin, sediment transport and investigation of hydraulic behavior of irrigation structures.

Javad Farhoudi received his PhD degree in Hydraulic Structures from Southampton University, UK in 1979, and he is currently a Distinguished Professor of Hydraulic Structures and River Engineering at the Department of Irrigation and Reclamation Engineering, Faculty of Agricultural Engineering and Technology (UTCAN) at the University of Tehran, Iran. He has served higher education in the field of Irrigation and Hydraulic Engineering since 1974, and worked on the design of hydraulic structures in Iran. Dr. Farhoudi has also served in several committees and commissions in the field of water resources engineering, such as ICOLD, ICID, IHP, and the Iranian Academy of Sciences, and has published numerous papers in refereed national and international journals and conferences in these areas of expertise. His research interests include scouring and pressure fluctuation encountered in stilling basins, as well as measuring structures.

Hossein Khalili Shayan received a BS degree in Water Engineering from Urmia University, Iran in 2009 and an MS degree from the University of Tehran, Iran in 2012. His research interests include open channel hydraulics, investigation of hydraulic behavior of irrigation structures, local scour at the downstream of hydraulic structures and seepage phenomena under diversion dams.

Reza Roshan received a BS degree in Irrigation Engineering in 1991 from Tehran University. He received his MS degree in Irrigation Structures in 1995 on the subject of vortex phenomenon; now, he is a $\mathrm{PhD}$ candidate from Razi University. His research interests include Hydraulic modeling studies and design of hydraulic structures. As a senior member of Iranian Hydraulic Association, he has published more than 30 papers in national and international journals and conferences. 